\title{
A BET-fajlagos felület, a humuszanyagok és további talajtulajdonságok összefüggéseinek vizsgálata jellemző hazai talajtípusokon
}

\author{
${ }^{1}$ MolnÁR Sándor, ${ }^{1}$ *BARNA Gyöngyi, ${ }^{1}$ DrASKOVITS Eszter, ${ }^{2}$ FÖldÉNYI Rita, \\ ${ }^{3}$ HERNÁDI Hilda, ${ }^{1}$ BAKACSI Zsófia, ${ }^{1,4}$ MAKÓ András \\ ${ }^{1}$ MTA ATK TAKI, Budapest \\ ${ }^{2}$ PE MK Soós Ernő Víztechnológiai KF Intézet, Nagykanizsa \\ ${ }^{3}$ PE GK Növényvédelmi Intézet, Keszthely \\ ${ }^{4}$ PE GK Talajtani és Környezetinformatikai Tanszék, Keszthely \\ (Beérkezett: 2019.03.05.; Elfogadva: 2019.05.21.)
}

\section{Bevezetés}

A fajlagos felület - az egységnyi tömegre (egységnyi térfogatra) vonatkoztatott felület - a szilárd anyagok alapvető anyagi tulajdonsága. A diszperz rendszerekben a fajlagos felület a részecskeméret csökkenéssel rohamosan nő. A törmelékes üledékes kőzetekben és a talajokban, mint polidiszperz rendszerekben, az elemi részecskék méret szerinti megoszlásán túl, a fajlagos felületet jelentősen befolyásolja az ásványi összetétel (elsősorban az agyagásványok mennyisége és minősége, a külső és a belső felületek aránya), a humuszkolloidok mennyisége és minősége, valamint a talaj sürüsége is (GREENLAND \& HAYES, 1981; BRADY, 1990; Dragun, 1998, SoKOŁOWSKA, 2011; SKIC et al., 2016; CIEŚlA et al., 2018). A talajokban az elemi részecskék olyan szerves-ásványi komplexumok formájában kapcsolódhatnak szerkezeti elemekké (mikro- és makroagregátmokká), amelyek fajlagos felületének tényleges nagyságát a kialakuló kötések és a létrejövő pórusméret-eloszlás is befolyásolja (DI GLÉRIA et al., 1957; THENG, 1974; FILEP, 1988; MAKÓ \& HERNÁDI, 2012). A szemcseméret, a fajlagos felület és a kémiai összetétel annyira szoros kapcsolatban áll egymással, hogy ezek egyedi szerepét sokszor nagyon nehéz elkülöníteni (FARRER \& COLEMAN, 1967; HOROWITZ \& ELRICK, 1987).

A fajlagos felület nagysága az üledékek és a talajok számos fizikai, kémiai tulajdonságát befolyásolja (SOKOŁOWSKA et al., 2004; RAWLINS et al., 2010, HAJNOS, 2011). Nagysága szoros összefüggést mutat a kationcserélő kapacitással (PETERSEN et al., 1996; SKIC et al., 2016). A talajok víztartó képessége (fóként az alacsony tenzió tartományban) szintén kapcsolatba hozható a fajlagos felülettel.hatással van a talajban zajló biológiai folyamatokra is. A talajszemcsék felszíne élettérként szolgálhat a mikroorganizmusoknak, valamint ezen a felszínen kötődhetnek meg a tápanyagok is; a szemcsék mérete és a baktériumok gyakorisága közötti szoros inverz korrelációt többen is kimutatták (DEFLAUN \& MAYER, 1983; YAMAMOTO \& LOPEZ, 1985; CHENU \& STOZKY, 2002).

Emberi behatásra módosulhat a fajlagos felület, ilyen pl. mezőgazdasági müvelés, agrotechnika, öntözés, trágyázás (JÓZEFACIUK et al., 2001; UTKAEVA,

*Levelezö szerző: BARNA GYÖNGYI, MTA ATK Talajtani és Agrokémiai Intézet, 1022

Budapest, Herman Ottó út 15.

E-mail: gyongyi.barna@ rissac.hu 
2007; BIEGANOwsKI et al., 2013). A különféle eredetű szervetlen és szerves szennyezők talajokban történő megkötődését, illetve mozgékonyságát a fajlagos felület nagysága és a töltésviszonyok alapvetően meghatározzák (DRAGUN, 1998; HERNÁDI \& MAKÓ, 2012). A talajok szennyeződés-tároló és -szürő funkciója többek közt a fajlagos felület alapján becsülhető (MAKó et al., 2017).

A talajok fajlagos felületének meghatározására számos mérési módszer áll rendelkezésre, amelyek közül a fizikai (és kémiai) adszorpciós módszerek a legelterjedtebbek (ZHU et al., 2013). Az üledékes rendszerek nagyfokú inhomogenitása és a szerves-ásványi komplexumok felületeinek összetettsége, valamint az alkalmazott adszorptívum fizikai-kémiai tulajdonságai miatt a fajlagos felület nagysága függ az alkalmazott mérési módszertől. A talajtani gyakorlatban az apoláros folyadékok és folyadékgőzök között a nitrogén és nitrogén-nemesgáz elegyek alkalmazása a legelterjedtebb. A poláros anyagok közül a vízgőzt (QUIRK, 1955; FINK \& JACKSON, 1973; DE JONG, 1999; SOKOŁOWSKA, 2011; SKIC et al., 2016); a különbözö szerves vegyületeket és azok gőzeit: etilén-glikolt (EG) (BOWER \& GOERTZEN, 1958; PENNELl et al., 1995), etilén-glikol-monoetil-étert (EGME) (CARTER et al., 1965; CERATO \& LUTENEGGER, 2002), illetve például metilénkék oldatot (CHEN et al., 1999; SANTAMARINA et al., 2002), p-nitrofenol oldatot (RISTORI et al., 1989) használnak adszorptívumként. A nitrogéngőzzel végzett mérések eredményeit általában a BRUNAUER, EMMETT és TELLER (1938) által bevezetett, a gázfázisból adszorbeálódó molekulák többrétegű adszorpcióját leíró izotermaegyenlet (BET-egyenlet) felhasználásával dolgozzák fel és $N_{2}-B E T$ fajlagos felületként adják meg.

A vízgőz adszorpciós-deszorpciós izotermák leírására is alkalmas BET modellel számolt fajlagos felület értékek egyéb, származtatott modellekkel (Aranovich-Donohue modell, Guggenheim-Andreson-de Boer modell) kis mértékben pontosíthatók (CIEŚLA et al., 2018).

Különböző agyagásvány-összetételű talajokon végzett mérések során kimutatták, hogy a nagyobb szmektit-tartalmú talajok fajlagos felületének nagyságát a $\mathrm{N}_{2}$ adszorpciós technika az EGME és metilinkékes mérésekhez képest jelentősen alulbecsli, viszont a kaolinites talajokban nem találtak ilyen szignifikáns eltérést a két mérési típus között (YUKSELEN \& KAYA, 2006). Ennek az a magyarázata, hogy az $\mathrm{N}_{2}$-BET mérés során a nitrogén molekulák kis méretük (kb. $16,2 \AA^{2}$ ) ellenére sem tudnak a duzzadó agyagásványok hármas rétegösszletei közötti térbe behatolni, mert azok szorosan kötödnek egymáshoz. Ugyanakkor ezek a belső felületek elérhetőek az adszorptívumok számára poláros mérési környezetben (SANTAMARINA et al., 2002).

A talajok $\mathrm{N}_{2}$-BET mérésekor lényeges azt is tisztázni, hogy mi történjen a talajok szerves anyagaival. Ezek egyrészt a talajok természetes összetevői, másrészt szerves anyagok elroncsolására alkalmas kivonószerek módosíthatják az elemi szemcsék felületét is és így befolyásolhatják a mért felület nagyságát. Az általános mérési gyakorlat azt ajánlja, hogy az $\mathrm{N}_{2}$-BET mérések előtt távolítsuk el a mintákból a szerves anyagokat (pl. hidrogén-peroxiddal, nátrium-hipokloriddal (MIKUTTA et al., 2005). 
A szerves anyagok eltávolításának hatását számos tanulmányban vizsgálták (BuRFORD et al., 1964; PENNELl et al., 1995; KAISER \& GUGGENBERGER, 2003; VDOVIĆ et al., 2019). Hazai csernozjom talajokon TOMBÁCZ és munkatársai (1996) végeztek hasonló méréseket. Az általános tapasztalat azt mutatja, hogy a szerves anyagok eltávolítása után a $\mathrm{N}_{2}$-BET fajlagos felületek minden esetben növekedtek. Az eredmények egyértelmüen azt mutatják, hogy a $\mathrm{N}_{2}$-BET fajlagos felület nem additív tulajdonság, vagyis a különféle talajalkotók (ásványi felületek, humuszanyagok) külön-külön mérhető fajlagos felülete a talajban nem adódik össze (PENNELl et al., 1995). A természetes szerves anyagok eltávolítása után jelentősen megnövekvő fajlagos felületet nemcsak a hordozó ásvány alapvetően nagyobb felületével, illetve a humusz-hidak elroncsolásával növekvő diszperzitás fokkal lehet magyarázni, hanem azzal is, hogy a peroxidos kezelést követően egyrészt nő a pórusok összmennyisége, másrészt olyan pórusok is hozzáférhetővé válnak a $\mathrm{N}_{2}$ molekulák számára, amelyet elötte a humuszanyagok elfedtek, eltömtek (TOMBÁCZ et al., 1996; 1998). A talajrészecskék humuszfedéseit HEIL \& SPOSITO (1995) pásztázó elektronmikroszkópos felvételekkel kísérletileg is bizonyították; agyagásványok és talajszemcsék természetes és mesterségesen kialakított humuszfedésének vizsgálata során bizonyították a pórusok elfedését TOMBÁCZ és munkatársai (1998). Ugyanakkor a humuszanyagok minőségének a fajlagos felületre gyakorolt hatásáról kevés szakirodalom áll rendelkezésre.

$\mathrm{Az}$ aggregátumokat stabilizáló kötőanyagok (szervesanyagok, mész) jelenléte egyrészt elösegíti, hogy a szerkezeti elemek belsejében több bezárt, a nitrogén molekulák számára hozzáférhetetlen pórus alakuljon ki; másrészt az agyagásvány felületekhez kötődő szerves molekulák (organominerális komplexumok), illetve talán a $\mathrm{CaCO}_{3}$ is lefedheti az agyagásvány felületeket (WAGAI et al., 2009).

Több szerző is foglalkozott az egyes talajosztályozási rendszertani egységeket átlagosan jellemző fajlagos felület értékek összehasonlításával, a tapasztalt eltérések értelmezésével. MAYER \& XING (2001) az USA-ban feltárt savanyú talajok teljes talajszelvényeiből gyüjtött mintákon vizsgálta a fajlagos felület és a teljes szerves anyag tartalmának kapcsolatát. BIEGANOWSKI és munkatársai (2013) a lengyel talajfizikai adatbázis egyes rendszertani egységeinek átlagos külső és teljes fajlagos felületét hasonlították össze. SOKOŁOWSKA és munkatársai (2002) lengyel öntéstalajok szervesanyag tartalmának $\mathrm{N}_{2}$-BET felülettel való kapcsolatát vizsgálták. Különböző mállottsági fokú (borneói és egyesült államokbeli) feltalaj minták humuszfedéseinek a fajlagos felület nagyságával való kapcsolatát vizsgálták WAGAI és munkatársai (2009).

Becslő módszerek alkalmazása esetén a fajlagos felületet olyan pedotranszfer függvényekkel (PTF) számolhatjuk, amelyeket különböző talajtulajdonságok alapján paraméterezhetünk. A paraméterekhez tartozó konstansok meghatározásához különféle statisztikai módszereket (ARNEPALLI et al., 2008; RAWLINS et al., 2010; WHITFIELD \& REID, 2013), mesterséges neurális hálózati modelleket is felhasználnak (BAYAT et al., 2013; JAHANBAN et al., 2018). WHITFIELD és REID (2013) úgy tapasztalta, hogy a kizárólag szemcseösszetétel alapján paraméterezett PTF-ek a fajlagos felület becslésekor nem nyújtanak 
kielégítő pontosságot, ezért a szerves anyagok fajlagos felületre gyakorolt hatását is figyelembe kell venni.

Világszerte számos kutatás foglalkozik a különféle talajtulajdonságok és a talajok fajlagos felülete közötti összefüggések feltárásával, azonban a hazai talajtípusokról meglehetősen kevés ilyen információ áll rendelkezésünkre. Jelen tanulmányunkban arra kerestünk választ, hogy (1) a talajok szemcseméreteloszlása, humusztartalma, a humuszanyagok minősége, mésztartalma és kémhatása milyen mértékben befolyásolja néhány jellegzetes hazai talajtípus fajlagos felületét; (2) a fenti talajtulajdonságok ismeretében milyen pontossággal becsülhető a talajok fajlagos felülete? A kérdésekre többváltozós statisztikai módszer alkalmazásával kerestük a válaszokat.

\section{Anyag és módszer}

\section{Talajminták leírása}

Jelen vizsgálat egy olyan nagyobb, átfogó kutatás része, amelyben a jellemző hazai talajtípusok talajszelvényeit az országos előfordulás arányában tártuk fel. Az eddig feldolgozott és az ebben a tanulmányban bemutatásra kerülő BET vizsgálatok adatbázisa 27 teljes talajszelvény 104 különböző genetikai szintjéből származó mintára épül (1. táblázat; 1. ábra). Az érvényben lévő hazai talajosztályozás (STEFANOVITS, 1963) fötípusait tekintve, a szelvények közel kétharmada barna erdőtalaj, 19\%-a csernozjom talaj, a kőzethatású talajok aránya pedig 10\%. Egy-egy szelvény váztalaj illetve réti talaj.

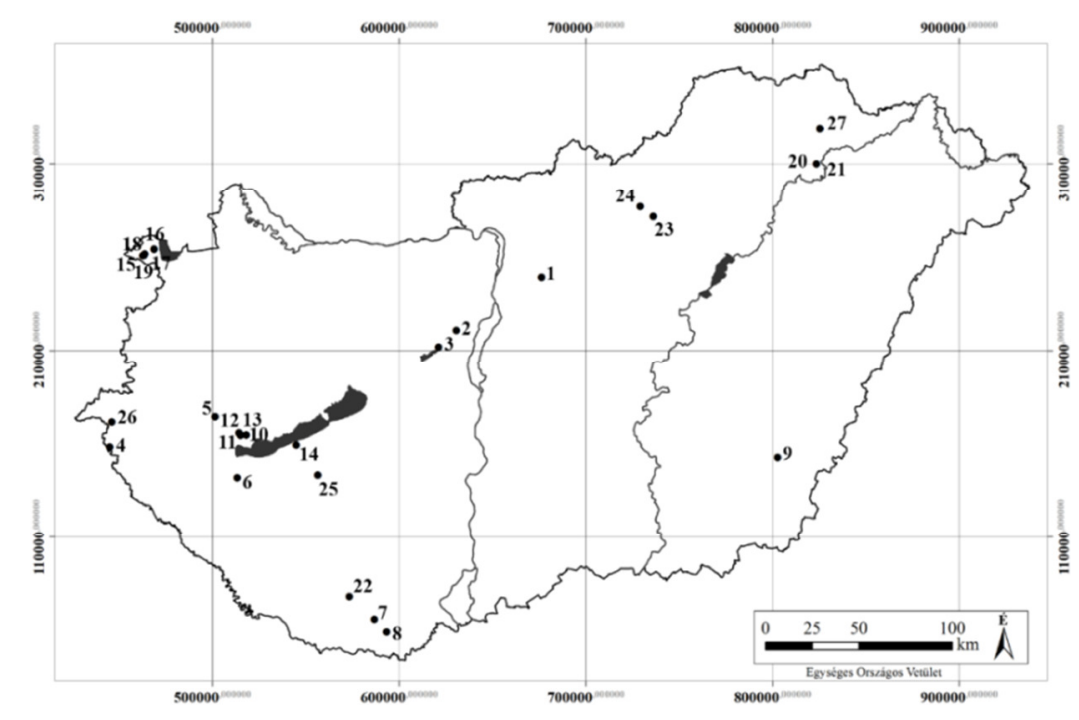

1. ábra

A talajminták származási helye (a szelvényfeltárások jelöléseinek magyarázatát az 1. táblázat tartalmazza) 
A BET-fajlagos felület, a humuszanyagok ... összefüggéseinek vizsgálata ...

\section{1. táblázat}

A talajszelvény-feltárások helye és a talajok besorolása a hazai genetikus talajosztályozás szerint (STEFANOVITS, 1963).

\begin{tabular}{|c|c|c|c|}
\hline Sorszám & Település (1) & Talaj fötípus (2) & Talajtípus és kódja (3) \\
\hline 1 & Gödöllö & barna erdőtalajok & csernozjom barna erdőtalajok (160) \\
\hline 2 & Martonvásár & csernozjomtalajok & erdőmaradványos csernozjom talajok (170) \\
\hline 3 & Kápolnásnyék & csernozjomtalajok & mészlepedékes csernozjom talajok (190) \\
\hline 4 & Velemér & barna erdőtalajok & pszeudoglejes barna erdőtalajok (120) \\
\hline 5 & Zalaszentlászló & réti talajok & típusos réti talajok (300) \\
\hline 6 & Sávoly & Váztalajok & humuszos homok talajok (50) \\
\hline 7 & Szalánta & barna erdőtalajok & agyagbemosódásos barna erdőtalajok (110) \\
\hline 8 & Siklós & barna erdőtalajok & Ramann-féle barna erdőtalajok (130) \\
\hline 9 & Békéscsaba & csernozjomtalajok & mészlepedékes csernozjom talajok (190) \\
\hline 10 & Vállus & barna erdőtalajok & agyagbemosódásos barna erdőtalajok (110) \\
\hline 11 & Keszthely & barna erdőtalajok & Ramann-féle barna erdőtalajok (130) \\
\hline 12 & Várvölgy & Váztalajok & humuszos homok talajok (50) \\
\hline 13 & Várvölgy & kőzethatású talajok & rendzina talajok (70) \\
\hline 14 & Balatonboglár & barna erdőtalajok & Ramann-féle barna erdőtalajok (130) \\
\hline 15 & Sopron & barna erdőtalajok & pszeudoglejes barna erdőtalajok (120) \\
\hline 16 & Sopron & barna erdőtalajok & Ramann-féle barna erdőtalajok (130) \\
\hline 17 & Sopron & kőzethatású talajok & humuszkarbonát talajok (60) \\
\hline 18 & Sopron & barna erdőtalajok & $\begin{array}{l}\text { erősen savanyú, nem podzolos barna } \\
\text { erdőtalajok }(90)\end{array}$ \\
\hline 19 & Sopron & kőzethatású talajok & humuszkarbonát talajok (60) \\
\hline 20 & Tarcal & barna erdőtalajok & Ramann-féle barna erdőtalajok (130) \\
\hline 21 & Tarcal & barna erdőtalajok & Ramann-féle barna erdőtalajok (130) \\
\hline 22 & Bicsérd & csernozjomtalajok & kilúgzott csernozjom talajok (180) \\
\hline 23 & Verpelét & kőzethatású talajok & nyirok talajok $(80)$ \\
\hline 24 & Recsk & barna erdőtalajok & pszeudoglejes barna erdőtalajok (120) \\
\hline 25 & Fiad & barna erdőtalajok & Ramann-féle barna erdőtalajok (130) \\
\hline 26 & Szalafö & barna erdőtalajok & pszeudoglejes barna erdőtalajok (120) \\
\hline 27 & Tolcsva & kőzethatású talajok & nyirok talajok $(80)$ \\
\hline
\end{tabular}

A 15 erdőtalaj szelvény zöme Ramann-féle, illetve pszeudoglejes barna erdőtalaj volt. Két agyagbemosódásos barna erdőtalaj, egy erősen savanyú, nem podzolos barna erdőtalaj és egy csernozjom barna erdőtalaj szelvényt is bevontunk a vizsgálatokba. A csernozjom talajok szintén változatos képet mutatnak, hiszen 
egy alföldi mészlepedékes csernozjom, egy típusos mészlepedékes csernozjom, egy erdőmaradványos csernozjom és egy kilúgozott csernozjom szelvény is feltárásra került. A kőzethatású talajok közül humuszkarbonát talajokat, nyirok talajokat és rendzinákat vizsgáltunk.

\section{Talajvizsgálatok}

A talajminták alapvizsgálatait a hazai talajvizsgálati módszertan gyakorlata szerint végeztük el (MSZ-08-0205-78; MSZ-08-0206-2-78; BUZÁS, 1988, 1993).

Vizsgálatunkba a humuszanyagok minőségét jellemző mutatót is be kívántunk vonni. A humuszanyagok jellemzésére többféle módszert is kidolgoztak, melyek többnyire különböző oldószerekkel elöállított talajkivonatok spektroszkópiás mérésén alapulnak. A Hargitai-féle módszer (HARGITAI, 1974, 1983) előnyei a könnyü kivitelezhetőség, a csekély vegyszerigény, valamint az, hogy az egyes talaj fötípusok jól elkülöníthető átlagos méröszámmal jellemezhetőek (csernozjomok 10; erdőtalajok 1-2; láp-, réti talajok 0,1 ; szikes talajok 0,01 ).

A módszer alapelve szerint a jó minőségü, nagy molekulájú kalciumionokhoz kötött humuszanyagok a nátrium-fluorid, a nyers szerves anyagok és kevésbé kedvező tulajdonságú humuszkomponensek (fulvosavak) nátrium-hidroxid oldatával vonhatók ki a talajból. A leszürt talajkivonatokat spektrofotométerrel kilenc hullámhosszon $(420 ; 465 ; 496 ; 533 ; 574 ; 619 ; 660 ; 726 ; 750$ nm) mérjük. A kapott extinkciós értékek számtani középértékeiböl $\left(\mathrm{E}_{\mathrm{NaF}}, \mathrm{E}_{\mathrm{NaOH}}\right)$ a $\mathrm{Q}$ stabilitási szám és a K humuszstabilitási koefficiens az (1) és (2) egyenlet alapján számítható, ahol (H) a Tyurin-féle összes humusztartalom.

$$
\begin{aligned}
& Q=\frac{E_{N a F}}{E_{N a O H}} \\
& \text { és } K=\frac{Q}{H}
\end{aligned}
$$

Mindkét mutató esetén a magasabb érték a kedvező minőségü, valódi humuszanyagok túlsúlyát jelzi a talajokban.

Elövizsgálataink alapján megállapítottuk, hogy a Hargitai-módszer érzékenységének alsó határa $0,5 \%$-os humusztartalomnál van, ezért ezt a vizsgálatot csak azokon a talajmintákon végeztük el, ahol előzetesen a humusztartalomra ennél nagyobb értékeket kaptunk.

A talajmintáink fajlagos felületét fizikai adszorpciós módszerrel határoztuk meg a MOTIM Zrt. mosonmagyaróvári laboratóriumában. A méréshez a Mircomeritics Flowsorb 2300 készüléket használtuk. A müszer mérési alapelve az, hogy a tényleges mérés megkezdése előtt a készülék DeSorb 2300A egysége a behelyezett mintákból termikus úton eltávoltítja a korábban felvett gőzöket, gázokat, miközben a minták tisztítására szolgáló 5.0 (99,999\% tisztaságú) nitrogén gázt áramoltat át rajtuk. Az így előkészített mintákat a Flowsorb 2300 TEST állomására helyezzük, ahol az adszorpciót folyékony nitrogén hőmérsékletén, $29,6 \% \mathrm{~N}_{2}$ tartalmú hélium-nitrogén gázeleggyel végezzük és az adszorbeált gáz térfogatát mérjük.

A fajlagos felület mérések eredményeit BET-egyenlettel dolgoztuk fel. 
A BET-fajlagos felület, a humuszanyagok ... összefüggéseinek vizsgálata ...

\section{Statisztikai vizsgálatok}

Az összefüggés-vizsgálatok statisztikai elemezéseihez az IBM SPSS 22.0.0.0 programcsomag Regression/Automatic Linear Modelling módszerét alkalmaztuk. A módszer előnye a hagyományos lineáris regressziós módszerrel (Regression/Linear) szemben a leghatékonyabb becslő változók automatikus kiválasztása és az automatikus adatelökészítés. (Mivel kevés magyar nyelvü leírás található, részletesen mutatjuk be az egyes lépéseket.) A hatékony becslö változók kiválasztása során a módszer csak azokat a független változókat keresi, melyek megfelelő kapcsolatban állnak a függő változóval. Ehhez két eljárást kínál fel: (1) a „Forward stepwise” szelekciós módszert és (2) „All-possible-subsets” módszert. Mindkét eljáráshoz több optimalizálási statisztikai módszer is felhasználható (korrigált Akaike-féle információs kritérium [AICC], korrigált R-négyzet, túlillesztés-megelőzési kritérium [ASE]), illetve a „Forward stepwise” módszer további kritériuma lehet még az F-statisztika $(\mathrm{P}<0,05)$ is. Az - opcionálisan választható - automatikus adatelőkészítés során az „Automatic Linear Modelling” módszer elvégzi (1) a hiányzó adatok pótlását (a változók típusától függően a változók átlagának, móduszának vagy a mediánnak a behelyettesítésével); (2) a naptári és időadatok időhosszá konvertálását; (3) a kategóriaváltozók azonosítását, a szignifikánsan nem különböző (P > 0,05) hatású változók összevonását; illetve (4) a kiugró értékek kiválasztását és helyettesítését. Az egyes változók kiugró értékeinek kiválasztásakor az eljárás a határértékeket az átlagtól történő háromszoros szórás távolságánál állítja be. Ezután a kiugró értékek becslést befolyásoló szerepének vizsgálatát végzi el az eljárás a Cook-féle távolság (Cook’s Distance) számítással. A kiugró és a becslést jelentősen befolyásoló értékek beazonosítása után az adatfeldolgozás során dönthetünk ezeknek a rekordoknak a teljes kizárásáról is.

Az SPSS „Automatic Linear Modelling” módszere lehetőséget nyújt a modellek pontosságának (,accuracy”), illetve stabilitásának javítására is azáltal, hogy a „standard model" opció helyett a ,boosting”, illetve a ,bagging” opció kiválasztásával a modellek sorozatát generálja, és felkínálja a legmegfelelőbb modellvariációkat (YANG, 2013; BHAT, 2016; HALL \& CATON, 2017).

Vizsgálataink jelenlegi szakaszában az „Automatic Linear Modelling” módszer „standard model” változatát használtuk. A becslő változók automatikus kiválasztása során teszteltük a szoftver összes opcióját. A statisztikai elemzéseket elvégeztük automatikus adatelőkészítéssel és anélkül is.

\section{Eredmények és következtetések}

A vizsgálatokba vont talajok mind talajgenetikailag, mind pedig fizikai és kémiai tulajdonságaikban nagyfokú heterogenitást mutatnak (2. táblázat). A mechanikai összetétel vizsgálatok alapján a talajminták a homok, vályogos homok, homokos vályog, homokos agyagos vályog, vályog, iszapos vályog, agyagos vályog, iszapos agyagos vályog és az agyag fizikai féleséget reprezentálják (2. ábra).

A talajok humusztartalom értékei is viszonylag tág határok között változtak. Ennek oka részben az is, hogy az összes talajszelvény összes szintjéből történt 
mérés. A minták negyedében a szerves szén mérésből számított humuszszázalék (H\%) értéke nem érte el a 0,5\%-ot sem. Az ilyen alacsony értékek leginkább a mérés során oxidálható nem humifikálódott szerves törmelékekböl vagy szervetlen alkotókból származnak. Ezért nem, vagy csak részben jellemzi az adott talajminta valódi humuszanyagainak mennyiségét. Hat százalékot meghaladó humusztartalmat három mintában mértünk. Ezek mindegyike a kőzethatású talajok (humuszkarbonát (60) és rendzina (70) talajok) felső humuszos szintjéből származott.

\section{2. táblázat}

A vizsgálatba vont talajok főbb talajtani jellemzöi

\begin{tabular}{|c|c|c|c|c|c|}
\hline & Átlag (1) & $\begin{array}{c}\text { Minimum } \\
(\mathbf{2})\end{array}$ & $\begin{array}{c}\text { Maximum } \\
(\mathbf{3})\end{array}$ & Szórás (4) & $\begin{array}{c}\text { Talajminták } \\
\text { száma (N) (5) }\end{array}$ \\
\hline $\begin{array}{c}\text { MSZ agyag (m\%) } \\
(\mathbf{6})\end{array}$ & 23,15 & 0,19 & 52,31 & 10,76 & 104 \\
\hline $\begin{array}{c}\text { MSZ por (m\%) } \\
(\mathbf{7})\end{array}$ & 45,84 & 8,23 & 69,54 & 16,44 & 104 \\
\hline $\begin{array}{c}\text { MSZ homok } \\
(\mathbf{m} \%)(\mathbf{8})\end{array}$ & 31,00 & 5,91 & 86,63 & 21,98 & 104 \\
\hline $\begin{array}{c}\text { Szerves C (m\%) } \\
(\mathbf{9})\end{array}$ & 0,91 & 0,05 & 5,26 & 0,97 & 104 \\
\hline $\mathbf{Q}(\mathbf{1 0})$ & 6,85 & 0,13 & 53,73 & 11,76 & 71 \\
\hline $\mathbf{K}(\mathbf{1 1})$ & 3,53 & 0,07 & 27,58 & 5,65 & 71 \\
\hline $\mathbf{C a C O} \mathbf{3}(\mathbf{m} \%)$ & 4,96 & 0,00 & 37,05 & 9,48 & 104 \\
\hline $\mathbf{p H}\left(\mathbf{H}_{\mathbf{2}} \mathbf{0}\right)$ & 7,07 & 4,15 & 9,40 & 1,30 & 104 \\
\hline $\mathbf{B E T}\left(\mathbf{m}^{\mathbf{2}} \mathbf{g}^{-\mathbf{1}}\right)$ & 19,98 & 0,40 & 59,95 & 12,87 & 104 \\
\hline
\end{tabular}

A humuszos szintekből $(\mathrm{H} \%>0,5)$ származó mintákon végzett humuszminőség vizsgálataink eredményeit részletesen bemutatjuk. Az adatok kiváló egyezést mutatnak a HARGITAI $(1974,1983)$ által közölt, különféle talaj főtípusokra jellemzőnek tartott $\mathrm{K}$ érték mérőszámokkal. Főtípus szinten a legalacsonyabb értékeket a váztalajoknál $\left(\mathrm{K}_{\min ,}=0,22 ; \mathrm{K}_{\max }=0,61 ; \mathrm{K}_{\mathrm{at}} \mathrm{gag}=0,41\right)$ és a közethatású talajoknál $\left(\mathrm{K}_{\min }=0,47 ; \mathrm{K}_{\max }=2,16 ; \mathrm{K}_{\text {átlag }}=0,91\right)$ mértük. A kőzethatású talajokon belül a leggyengébb humuszminőséget a nagy szervesanyag tartalmú $(H \%=6,50-8,15)$ rendzina $(70)$ talajokban $\left(\mathrm{K}_{\min }=0,53 ; \mathrm{K}_{\max }=0,61 ; \mathrm{K}_{\text {átlag }}=\right.$ $0,57)$, a legjobbat a humuszkarbonát (60) talajokban $\left(\mathrm{K}_{\min }=1,27 ; \mathrm{K}_{\max }=2,16\right.$; $\mathrm{K}_{\text {átlag }}=1,72$ ) tudtuk kimutatni. 


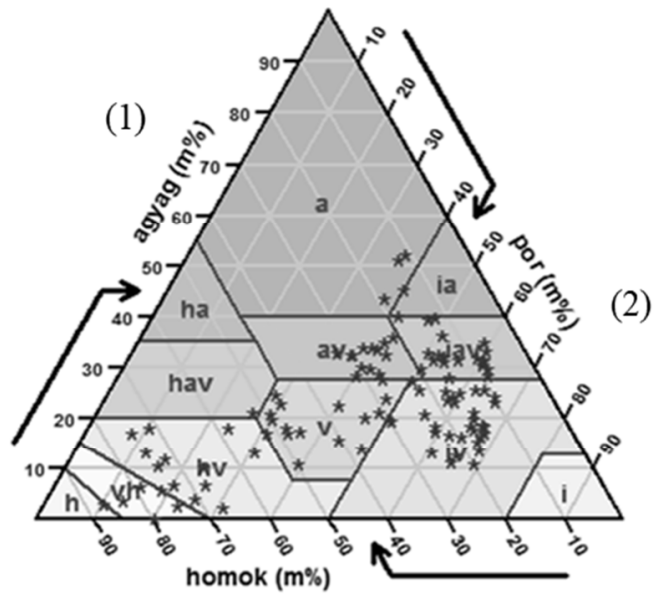

(3)

2. ábra

A talajminták MSZ szerinti mechanikai összetétele az USDA háromszögdiagramon

A barna erdőtalajok humuszminőségi mutatói tág határok közt változtak $\left(\mathrm{K}_{\min }=0,07 ; \mathrm{K}_{\max }=6,12 ; \mathrm{K}_{\text {átlag }}=1,13\right)$; a leggyengébb humuszminőség az erősen savanyú, nem podzolos barna erdőtalajokat $(90)\left(\mathrm{K}_{\min }=0,16 ; \mathrm{K}_{\max }=0,26\right.$; $\left.\mathrm{K}_{\text {átlag }}=0,21\right)$ és az agyagbemosódásos barna erdőtalajokat $(110)\left(\mathrm{K}_{\min }=0,16\right.$; $\left.\mathrm{K}_{\max }=1,40 ; \mathrm{K}_{\text {attag }}=0,56\right)$ jellemezte, míg a Ramann-féle barna erdőtalajoknál (130) $\left(\mathrm{K}_{\min }=0,13 ; \mathrm{K}_{\max }=3,77 ; \mathrm{K}_{\text {atlag }}=1,35\right)$ és a csernozjom barna erdőtalajoknál (160) $\left(\mathrm{K}_{\min }=2,40 ; \mathrm{K}_{\max }=6,12 ; \mathrm{K}_{\mathrm{attag}}=4,06\right)$ lényegesen jobb humuszminőségi mutatókat mértünk. A legjobb humuszminőségre (hosszú szénláncú, elágazó, stabil óriásmolekulák) utaló $\mathrm{K}$ értékeket - a szakirodalommal egyezően - a csernozjom talajoknál mértük $\left(\mathrm{K}_{\min }=1,68 ; \mathrm{K}_{\max }=27,58 ; \mathrm{K}_{\text {átlag }}=11,22\right)$. A fötípuson belül a típusos mészlepedékes csernozjom < kilúgzott csernozjom < erdőmaradványos csernozjom < alföldi mészlepedékes csernozjom sorrendben nőtt a $\mathrm{K}$ értéke $\left(\mathrm{K}_{\text {átlag }}=4,98<8,58<14,30<14,80\right)$. A humuszminőség általában jelentősen eltért a minták mélység szerinti megoszlása szerint is. A karbonátos réti talaj (300) szelvényben a felszín közelében sok, de kedvezötlen minőségü $(\mathrm{H} \%=5,49, \mathrm{~K}=$ 0,45 ) humuszanyagot, a mélyebb rétegekben pedig kevesebb, de sokkal kedvezőbb tulajdonságú $(\mathrm{H} \%=1,44 ; \mathrm{K}=4,01)$ humuszformákat tudtunk kimutatni. A barna erdőtalajok legfelső genetikai szintjeinek humuszminőségét találtuk a leggyengébbnek ( $\left.\mathrm{K}_{\text {atlag }}=0,68\right)$, majd a mélységgel a humuszminőség kis mértékben javult a második és harmadik mintázott genetikai szintekben $\left(\mathrm{K}_{\text {átlag }}=1,24\right.$ és $K_{\text {átlag }}=1,60$ ), végül a 4 . és 5 . szintekben újra humuszminőség romlást tapasztaltunk $\left(K_{\text {átlag }}=1,40\right.$ és $\left.K_{\text {atlag }}=0,50\right)$. Hasonló tendenciákat, még nagyobb eltérésekkel tapasztaltunk a csernozjom talajok fötípusánál. Az első mintázott genetikai szinttől lefelé haladva a következő átlagos humuszstabilitási koefficienseket mértük: $\mathrm{K}_{\text {attlag, } 1 . \text { szint }}=7,32 ; \quad \mathrm{K}_{\text {atlag,2.szint }}=8,91 ; \quad \mathrm{K}_{\text {átlag,3.szint }}=14,43 ; \quad \mathrm{K}_{\text {attlag, } 4 \text {.szint }}=18,66 ;$ $\mathrm{K}_{\text {átlag,5.5zint }}=7,04$. A felső (sok esetben müvelés alatt álló) genetikai szintekböl 
származó minták kisebb humuszstabilitási értékei talán részben a nagyobb biológiai aktivitással, a humifikáció mértékénél nagyobb szerves anyag bomlási sebességgel magyarázhatóak.

Az N $\mathrm{N}_{2}$-BET méréseink a kezeletlen (szerves anyagokat tartalmazó) mintákból történtek. Ismerve a szerves anyagok eltávolításának szerkezetmódosító hatását a szervetlen ásványi alkotókra, elsősorban az agyagásványokra - csak természetes, eredeti mintával dolgoztunk és a humuszalkotók hatását statisztikai módszerekkel kívántuk jellemezni.

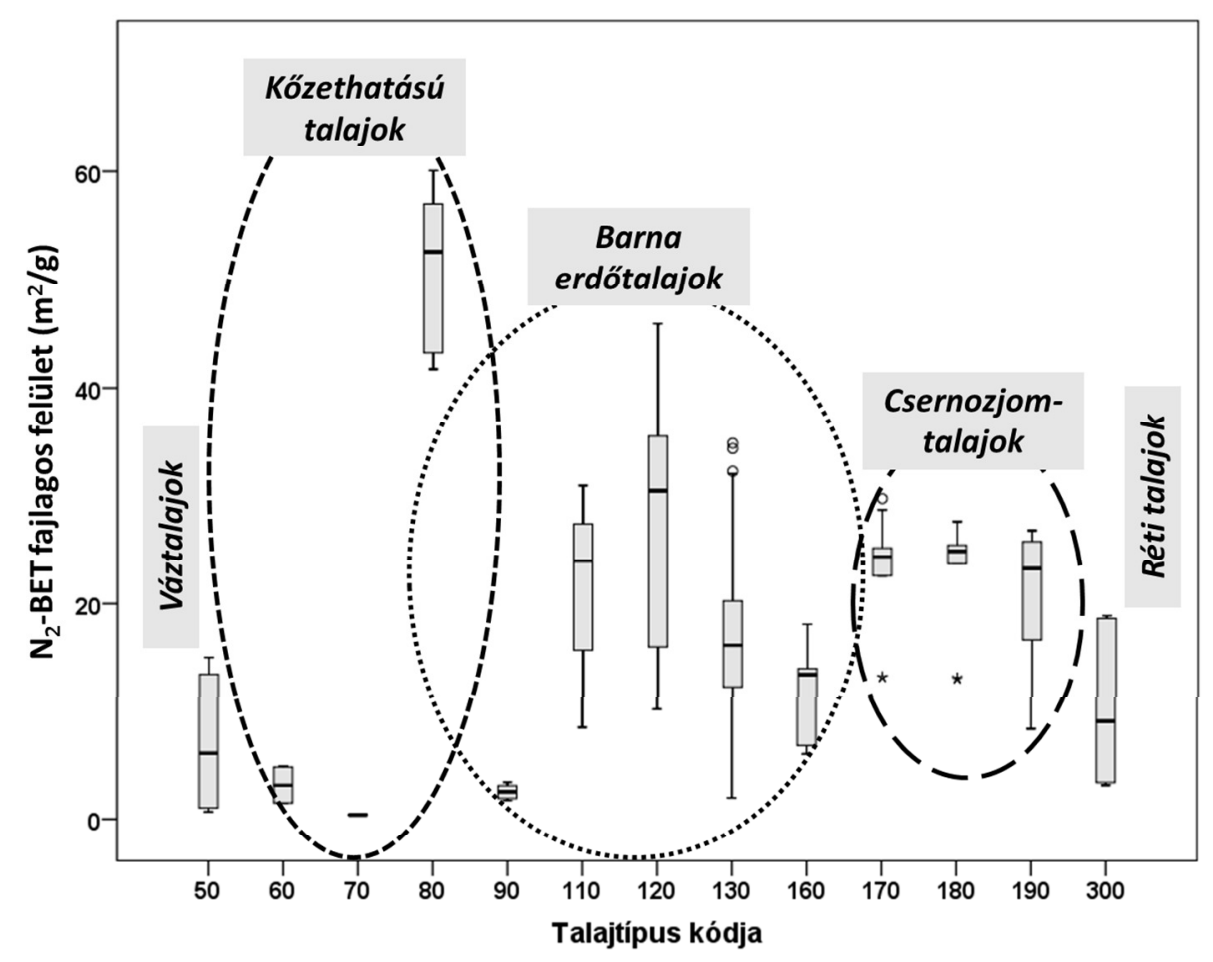

3. ábra

A talajminták $\mathrm{N}_{2}$-BET felülete talajosztályozási egységenként

A minták $\mathrm{N}_{2}$-BET fajlagos felületének nagysága széles határok közt változott, a legalacsonyabb $\left(0,4 \mathrm{~m}^{2} \mathrm{~g}^{-1}\right)$ és a legmagasabb $\left(\sim 60 \mathrm{~m}^{2} \mathrm{~g}^{-1}\right)$ értékek között 150 -szeres volt a különbség. A legkisebb fajlagos felületek az öt százalék alatti agyagtartalmú rendzina (70), humuszos homok (50) és humuszkarbonát (60) talajokban, míg a legnagyobbak a 40-50\% agyagtartalmú nyiroktalajokban (80) fordultak elő (3. ábra). A barna erdőtalajok főtípusán belül talajtípusonként és azon belül genetikai szintenként is nagy eltéréseket tapasztaltunk $\left(\mathrm{N}_{2}-\mathrm{BET}_{\min }=1,72 ; \quad \mathrm{N}_{2}-\mathrm{BET}_{\max }=45,92\right.$; $\left.\mathrm{N}_{2}-\mathrm{BET}_{\text {átlag }}=19,09\right)$. A legkisebb fajlagos felületet e fötípuson belül az erösen savanyú, nem podzolos barna erdőtalaj (90) mintákon mértiik, míg a legnagyobb értékeket a pszeudoglejes barna erdőtalajok (120) agyag-felhalmozódási szintjeiben. A 
csernozjom talajok főtípusába tartozó minták a fajlagos felület értékeket tekintve jóval homogénebbek voltak $\left(\mathrm{N}_{2}-\mathrm{BET}_{\min }=8,31 ; \mathrm{N}_{2}-\mathrm{BET}_{\max }=29,76 ; \mathrm{N}_{2}-\mathrm{BET}_{\text {atlag }}=21,85\right)$. Az átlagosnál kisebb fajlagos felület értékeket $\left(\mathrm{N}_{2}-\mathrm{BET}=8,31\right.$; és 8,76$)$ a csernozjom talajok nagy mésztartalmú lösz talajképző kőzetében mértük. A szelvényen belüli, illetve szintenkénti fajlagos felület eltérésekröl több szerző is beszámolt (SOKOŁOWSKA et al., 2002, 2004; JÓZEFACIUK et al., 2006; UTKAEVA, 2007).

A továbbiakban a talajok néhány fizikai és kémiai paramétere és a $\mathrm{N}_{2}$-BET fajlagos felület közötti kapcsolatot vizsgáltuk. A 4. ábra regressziós görbéin bemutattuk a fajlagos felület kapcsolatát a vizsgált talajtulajdonságokkal, majd az egyes változók közti lineáris kapcsolat nagyságát és irányát jellemeztük a Pearson-féle korrelációs mátrix számításával (3. táblázat). Az elemzések alapján jól látható, hogy a talajok mechanikai összetétele (föként az agyag- és homoktartalom) mutatja a legszorosabb kapcsolatot a fajlagos felülettel, de igazolható a mész- és humusztartalom negatív előjelű (önmagában nem túl szoros) kapcsolata is a $\mathrm{N}_{2^{-}}$ BET felület értékekkel. A korrelációs vizsgálat gyenge pozitív kapcsolatot mutat a fajlagos felület értékek és a humuszstabilitási mutató közt. A Pearson-féle korrelációs mátrix nem mutat igazolható kapcsolatot a talaj pH és a fajlagos felület értékek közt. Figyelemre méltó még a humuszstabilitási mutató és a mechanikai összetétel (agyag- és homoktartalom) szignifikáns kapcsolata is: a vizsgált adatbázison a nagyobb agyagtartalmú talajok humuszmolekuláinak mért stabilitása általában nagyobb.
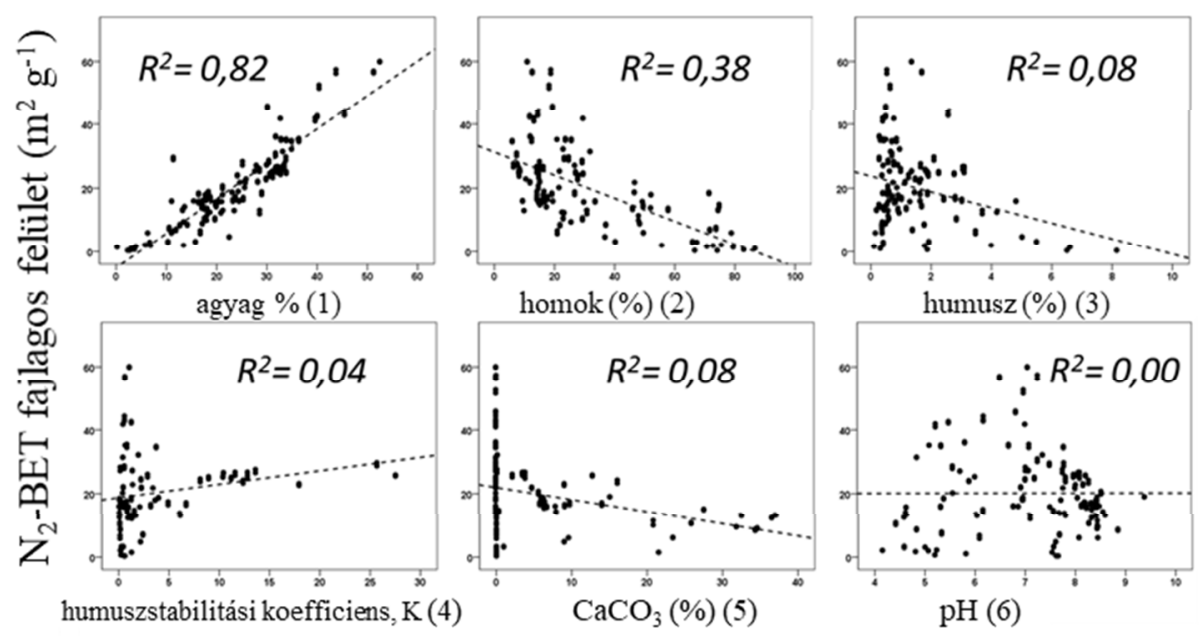

4. ábra

A talajminták $\mathrm{N}_{2}$-BET felületének kapcsolata a többi talajtulajdonsággal

Az „Automatic Linear Modelling” módszerrel vizsgáltuk a különböző talajtulajdonságok együttes hatását a talaj külső $\left(\mathrm{N}_{2}\right.$-BET) fajlagos felületére. Elsőként a teljes mintacsoporton végeztük el statisztikai elemzéseinket; ebben az esetben nem tudtuk figyelembe venni a humuszminőség vizsgálatok eredményeit, 
hiszen ezeket a méréseket csak a 0,5\%-nál nagyobb humusztartalmú, főként felső rétegekből származó mintákon végeztük el. Az $5 A$. ábrán mutatjuk be a statisztikai módszerrel kapott legjobb modell jellemzőit. A modellben csak azokat a független változókat vettük figyelembe, melyek megfelelöen szoros kapcsolatban (vagyis a 0,05 alatti szignifikancia-együttható szerint) álltak a függő $\left(\mathrm{N}_{2}\right.$ - $\left.\mathrm{BET}\right)$ változóval. Így végül a $\mathrm{N}_{2}$-BET fajlagos felülettel összefüggő vizsgált talajtulajdonságok száma háromra volt redukálható. A modell pontossága megfelelő (Adj. $\mathrm{R}^{2}=0,86$ ). Jól látható, hogy a talajváltozók közül a legfontosabb a talajok agyagtartalma (fontossága a modellben az összes hatás 90\%-ának felel meg, $\mathrm{P}<0,01$, regressziós együttható: 1,0). A második legfontosabb tényező a talajok humusztartalma. Ennek hatása negatív (regressziós együttható: -2,32), a tényező fontossága $7 \%(\mathrm{P}<0,01)$. A mésztartalom ugyancsak negatív hatású (regressziós együttható: -0,26), ennek fontossága $~ 3 \%(\mathrm{P}<0,05)$.

\section{3. táblázat}

A vizsgált paraméterek közötti kapcsolatrendszer (Pearson-féle korrelációs mátrix)

Pearson-féle korreláció

\begin{tabular}{|c|c|c|c|c|c|c|c|c|}
\hline & $\begin{array}{c}\text { agyag } \\
\%(1)\end{array}$ & $\begin{array}{l}\text { por \% } \\
\text { (2) }\end{array}$ & $\begin{array}{c}\text { homok \% } \\
(3)\end{array}$ & $\begin{array}{c}\text { humusz } \\
\%(4)\end{array}$ & $\begin{array}{l}\text { humusz- } \\
\text { minőség } \\
\text { (K) (5) }\end{array}$ & $\begin{array}{c}\mathrm{CaCO}_{3} \\
\%\end{array}$ & $\begin{array}{c}\mathbf{p H} \\
\left(\mathbf{H}_{2} \mathbf{O}\right)\end{array}$ & $\begin{array}{c}\mathrm{N}_{2}-\mathrm{BET} \\
\mathrm{m}^{2} \mathrm{~g}^{-1}\end{array}$ \\
\hline $\begin{array}{c}\text { agyag \% } \\
\text { (1) }\end{array}$ & 1 & $0,27 * *$ & $-0,69 * *$ & $-0,17 *$ & $0,33 * *$ & $-0,20 * *$ & 0,04 & $0,91 * *$ \\
\hline $\begin{array}{c}\text { por \% } \\
(2) \\
\end{array}$ & & 1 & $-0,88 * *$ & $-0,05$ & 0,06 & $0,23 * *$ & $0,43 * *$ & $0,23 * *$ \\
\hline $\begin{array}{c}\text { homok } \\
\text { \% (3) }\end{array}$ & & & 1 & 0,12 & $-0,22 * *$ & $-0,07$ & $-0,34 * *$ & $-0,61 * *$ \\
\hline $\begin{array}{c}\text { humusz } \\
\%(4)\end{array}$ & & & & 1 & $-0,001$ & $-0,11$ & 0,02 & $-0,28 * *$ \\
\hline $\begin{array}{c}\text { humusz- } \\
\text { minőség } \\
(\mathbf{K})(5)\end{array}$ & & & & & 1 & 0,15 & $0,39 * *$ & $0,20 *$ \\
\hline $\begin{array}{c}\mathrm{CaCO}_{3} \\
\%\end{array}$ & & & & & & 1 & $0,53 * *$ & $-0,28 * *$ \\
\hline $\begin{array}{c}\mathbf{p H} \\
\left(\mathbf{H}_{2} \mathbf{O}\right) \\
\end{array}$ & & & & & & & 1 & 0,002 \\
\hline $\begin{array}{c}\mathbf{N}_{2} \text {-BET } \\
\mathbf{m}^{2} \mathbf{g}^{-1}\end{array}$ & & & & & & & & 1 \\
\hline
\end{tabular}

Az 5B. ábra a 0,5\%-nál nagyobb humusztartalmú mintacsoporton alkotott legjobb modellt mutatja be. Ebben az esetben a talajok humusztartalma mellett a Hargitai-féle humuszminőségi koefficiens fajlagos felületre gyakorolt hatását is vizsgálni tudtuk. A modell némileg pontosabb (Adj. $R^{2}=0,88$ ) a teljes mintacsoporton kialakított legjobb modellnél. Az agyagtartalom fajlagos felületre 
gyakorolt hatása ebben az esetben is meghatározó volt (fontosság: 89\%; $\mathrm{P}<0,01$; regressziós együttható: 1,1). A többi változó hatáserőssége, szignifikanciája és regressziós együtthatója a következő sorrendben követte egymást: humusztartalom (fontosság: 5\%; $\mathrm{P}<0,01$; regressziós együttható: -1,23); humuszminőségi koefficiens, $\mathrm{K}$ érték (fontosság: $3 \% ; \mathrm{P}<0,01$; regressziós együttható: $-0,35$ ); $\mathrm{pH}$ (fontosság: $2 \% ; \mathrm{P}<0,01$; regressziós együttható: 1,07). A talajok mésztartalma és homoktartalma is befolyásolta a modell pontosságát (ezek együttes fontossága $1 \%$ volt), azonban ezeknek a tényezőknek a hatása nem volt szignifikáns $(P>0,05)$.

A fenti modellek az „Automatic Linear Modelling” módszer „Forward stepwise" szelekciós moduljával készültek, melyek optimalizálásához a korrigált Akaike-féle információs kritériumot (AICC) használtuk. Eredményeinket összevetettük a „Forward stepwise” és az „All-possible-subsets” szelekciós modul mindegyik optimalizálási kritériumának használatával (korrigált R-négyzet, túlillesztés-megelőzési kritérium [ASE], illetve F-statisztika) készült modellekkel is. Tapasztalataink szerint a modellek pontossága, illetve az egyes becslő változók fontossága és szignifikanciája nem változott jelentősen a különféle szelekciós és optimalizálási eljárások hatására. Az automatikus adatelőkészítés használata ugyanakkor kis mértékben (1-2\%-kal) növelte a modellek pontosságát.

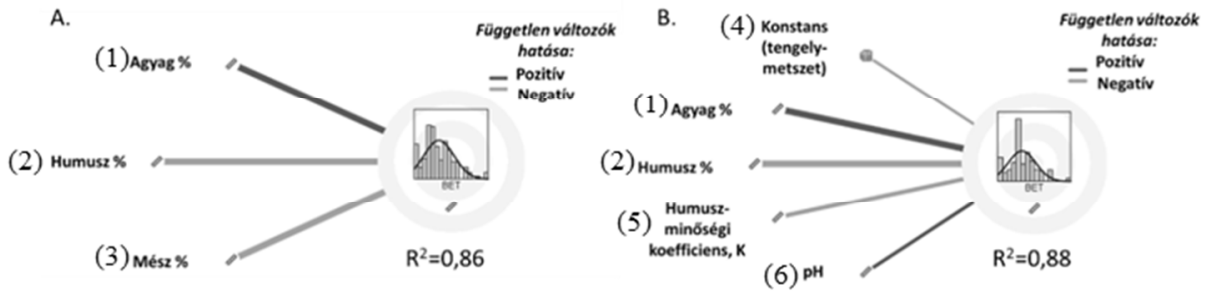

5. ábra

A $\mathrm{N}_{2}$-BET fajlagos felületet befolyásoló talajtulajdonságok modelljei. A.: teljes adatsor $(\mathrm{N}=204)$; B.: a 0,5\%-nál nagyobb humusztartalmú minták adatsora $(\mathrm{N}=132)$

(A vonalak vastagsága a hatások erősségét mutatja.)

A fajlagos felület és az agyagtartalom szoros pozitív kapcsolata a szakirodalomból jól ismert (pl. BANIN \& AMIEL, 1970; PETERSEN et al., 1996; SOKOŁOWSKA et al., 2002, 2004; JóZEFACIUK et al., 2006; WAGAI et al., 2009). A humuszanyagok felületcsökkentő hatásáról már inkább megoszlanak a vélemények (pl. BURFORD et al., 1964; THENG et al., 1999; SOKOŁOWSKA et al., 2002, 2004; UTKAEVA, 2007; KÖGEL-KNABNER et al., 2008), de a szakirodalmak általában megerösítik az általunk tapasztaltakat. A talajok mésztartalmának $\mathrm{N}_{2}$-BET felület csökkentő hatásáról kevesebb a rendelkezésre álló adat, de több szerző is hasonló eredményre jutott (pl. HOLFORD \& MATTINGLY, 1975; AlEKSEEV et al., 2008; LUCKE \& SCHMIDT, 2015). A humuszminőséget jellemző K koefficiens negatív hatását (vagyis a stabil, nagy molekulájú szénláncok kialakulásának fajlagos felületet csökkentő hatását) tudomásunk szerint jelen közleményben vizsgálták elöször, bár a szakirodalom egyéb módszerekkel igazolta már a nagy molekulájú 
humuszanyagok pórus-elzáró és ásványi felület lefedő hatásait (HEIL \& SPOSITO, 1995).

A pH és a $\mathrm{N}_{2}$-BET fajlagos felület pozitív kapcsolatát a többváltozós modellekben nehezebben tudjuk értelmezni. Valószínüsíthető, hogy mivel a $\mathrm{pH}$ növekedésével az ásványi felületek változó negatív töltéseinek mennyisége is növekszik és ezáltal a felületek polaritása is nö, a $\mathrm{N}_{2}$ gáz molekulák megkötődésének erőssége is növekszik (a $\mathrm{N}_{2}$ a kevésbé poláros felületeken sokkal gyengébben kötődik, mint a poláros ásványi felületeken) (MAYER, 1999).

A következőkben azt vizsgáltuk, hogy a talajok $\mathrm{N}_{2}$-BET fajlagos felületét mennyiben befolyásolhatják olyan egyéb (általunk nem mért) talajtulajdonságok, amely tulajdonságokra legfeljebb a talajok rendszertani helyéből (talajtípus, fötípus) következtethetünk (az egyes rendszertani egységek számos ismert és kevésbé ismert talajjellemzőt egyesítenek magukban). Az „Automatic Linear Modelling” módszer lehetőséget ad arra, hogy kategóriaváltozóknak a hatását is megvizsgáljuk a modellekben, így megvizsgáltuk a talajok fötípusának, illetve a talajtípusoknak a szerepét a $\mathrm{N}_{2}$-BET fajlagos felület becslő modellekben. A 6. ábrán a talajok fötípusának szerepét mutatjuk be a becslő modellekben. A 6A. ábra a teljes mintacsoporton kialakított legpontosabb $\left(\mathrm{Adj} . \mathrm{R}^{2}=0,92\right)$ modellt ábrázolja, ahol a szignifikáns hatású talajtulajdonságok - fontossági sorrendben a következők: agyagtartalom (fontosság: 49\%; $\mathrm{P}<0,01$; regressziós együttható: 0,82 ); humusztartalom (fontosság: $25 \%$; $\mathrm{P}<0,01$; regressziós együttható: -3,40); talajok fötípusa (fontosság: 16\%; $\mathrm{P}<0,01$; regressziós együttható: 11,82); mésztartalom (fontosság: 7\%; $\mathrm{P}<0,01$; regressziós együttható: -0,28); homoktartalom (fontosság: $3 \%$; $\mathrm{P}<0,01$; regressziós együttható: -0,09). A $6 B$. ábra a $0,5 \%$ feletti humusztartalmú talajok csoportjára kifejlesztett modellt (Adj. $\left.\mathrm{R}^{2}=0,89\right)$ mutatja be. Itt a becslő változók fontossági sorrendje a következőképpen alakult: agyagtartalom (fontosság: 77\%; $\mathrm{P}<0,01$; regressziós együttható: 0,91); humusztartalom (fontosság: $8 \% ; \quad \mathrm{P}<0,01 ;$ regressziós együttható: -2,26); Hargitai-féle humuszminőségi koefficiens (fontosság: 6\%; $\mathrm{P}<0,01$; regressziós együttható: 0,61); talajok fötípusa (fontosság: $5 \%$; $\mathrm{P}<0,01$; regressziós együttható: 5,49); mésztartalom (fontosság: 3\%; $\mathrm{P}<0,01 ;$ regressziós együttható: $-0,38$ ); $\mathrm{pH}$ (fontosság: $1 \% ; \mathrm{P}<0,01$; regressziós együttható: 0,92). Jól látható módon a fajlagos felület becslö modellek pontossága javult a talajok fötípusának figyelembevételével. A pontosságot tovább növelte, ha a fötípusok helyett a talajtípusokat választottuk kategória változóként (A. esetben Adj. $R^{2}=0,93$; . esetben Adj. $\mathbf{R}^{2}=0,92$ ), ez esetben azonban az egyes taxonómiai csoportba tartozó minták száma nagyon változó volt, a modellek - adott mintaszámok mellett nehezen voltak értelmezhetőek. A taxonómiai egységek kategóriaváltozóként történő bevonásával elért modell pontosság növekedés arra utal, hogy a becslő modellek pontosításának egyik lehetséges módja lehet a későbbiekben (egy nagyobb adatbázis esetében) az, ha rendszertani egységenként (fótípus, de inkább típus vagy altípus szinten) külön-külön vizsgáljuk az egyes mért talajtulajdonságok hatását az $\mathrm{N}_{2}$-BET fajlagos felületre. Továbbá szükség lehet a humuszos és humuszmentes $\mathrm{N}_{2}$-BET fajlagos felületek vizsgálatára és összehasonlító elemzésére is. 


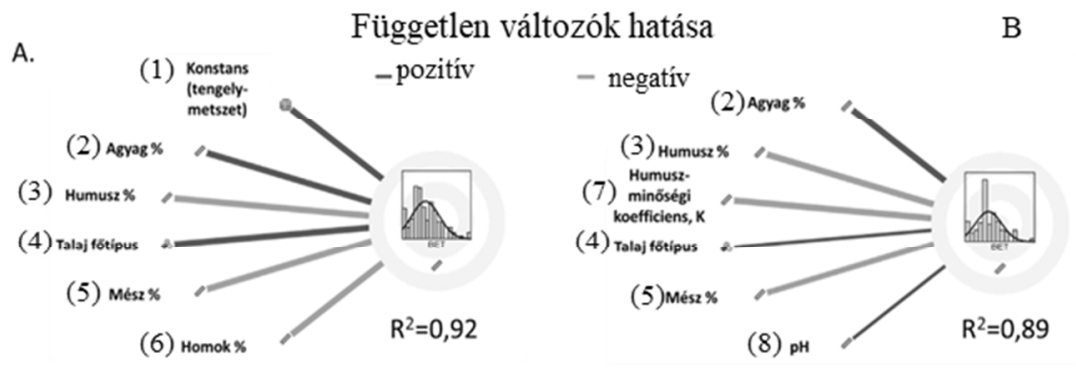

6. ábra

A $\mathrm{N}_{2}$-BET fajlagos felületet befolyásoló talajtulajdonságok modelljei (a talajosztályozás fötípusaival, mint kategóriaváltozóval kiegészítve). A.: teljes adatsor (N=204);

B.: a 0,5\%-nál nagyobb humusztartalmú minták adatsora $(\mathrm{N}=132)$

(A vonalak vastagsága a hatások erősségét mutatja.)

\section{Összefoglalás}

Tanulmányunkban 27 különböző hazai talajszelvényben vizsgáltuk, hogy a talajok $\mathrm{N}_{2}$-BET fajlagos felületét mely talajtulajdonságok milyen mértékben befolyásolják.

Az egytényezős elemzések alapján elmondható, hogy a talajok mechanikai összetétele mutatja a legszorosabb kapcsolatot a fajlagos felülettel, az agyagtartalommal szoros pozitív kapcsolat van, ugyanakkor a homoktartalom növekedésével a fajlagos felület csökken. Igazolható a mész- és humusztartalom negatív előjelü nem túl szoros kapcsolata is a $\mathrm{N}_{2}$-BET felület értékekkel. A korrelációs vizsgálat gyenge pozitív kapcsolatot mutat a Hargitai-féle humuszstabilitási mutatóval. A talaj kémhatása és fajlagos felület közötti kapcsolatot nem tudtuk igazolni.

Vizsgáltuk a különböző talajtulajdonságok együttes hatását is a talaj $\mathrm{N}_{2}$-BET fajlagos felületére, valamint a talajok fötípusának, illetve a talajtípusoknak a szerepét. A teljes adatbázis alapján a $\mathrm{N}_{2}-\mathrm{BET}$ fajlagos felület kialakításában a legfontosabb tényezők az agyagtartalom, majd a humusztartalom, végül a mésztartalom. Amennyiben a talajok humuszanyagainak minőségéről is rendelkezünk információkkal, akkor az agyagtartalom, a humusztartalom, a humuszminőség és kémhatás azok a talajtulajdonságok, amelyek elsősorban felelösek a talajok a $\mathrm{N}_{2}$-BET fajlagos felületének kialakításáért. Megállapítottuk, hogy a fajlagos felületet becslö modellek pontossága tovább javítható a talajok rendszertani besorolásának (fötípus, típus), mint kategóriaváltozónak figyelembevételével. A talajok rendszertani helyének ismerete ugyanis számos olyan talajjellemzőről, azok együttes hatásairól nyújt közvetett információt, melyekről egyébként nem rendelkezünk közvetlen mérési eredménnyel.

Kulcsszavak: fajlagos felület, agyagtartalom, humusztartalom, humuszminőség, $\mathrm{N}_{2}$-BET 


\section{Köszönetnyilvánítás}

Köszönjük Hauk Gabriellának a fajlagos felület mérésekben nyújtott segítségét.

Kutatásunkat a Nemzeti Kutatási, Fejlesztési és Innovációs Hivatal (NKFIH) K119475 sz. és KH-124765 pályázatok támogatásával végeztük.

\section{Irodalom}

Alekseev, A.O., Alekseeva, T.V., Hajnos, M., Sokołowska, Z., Kalinin, P.I. \& BORISOV, A.V., 2008. Modification of the mineralogical composition and surface properties of soils as related to steppe climate dynamics in historical time. Eurasian Soil Science. 41 (13). 1424-1432.

Arnepalli, D.N., Shanthakumar, S., Hanumantha, R.B. \& Singh, D.N., 2008. Comparison of methods for determining specific-surface area of fine-grained soils. Geotechnical and Geological Engineering. 26. 121-132.

BANIN, A. \& AMIEL, A., 1970. A correlative study of the chemical and physical properties of a group of natural soils of Israel. Geoderma. 3. 185-198.

BHAT, M.A., 2016. The predictive power of reasoning ability on academic achievement. International Journal of Learning, Teaching and Educational Research. 15. 79-88.

Bieganowski, A., WitkowskA-WalcZAK, B., Gliñski, J., SokoŁowskA, Z., SŁAWIÑski, C., BrZEZIÑska, M. \& WŁodArcZYK, T., 2013. Database of Polish arable mineral soils: a review. International Agrophysics. 27. 335-350.

BAYAT, H., ERSAHIN, S. \& HEPPER, E.N., 2013. Improving estimation of specific surface area by artificial neural network ensembles using fractal and particle size distribution curve parameters as predictors. Environmental Modeling and Assessment. 18. 605-614.

BOwER, C.A. \& GOERTZEN, J.O., 1958. Surface area of soils and clays by an equilibrium ethylene glycol method. Soil Science. 87 (5). 289-292.

BRADY, N., 1990. The nature and properties of soils. MacMillan Publishing Company. New York.

Brunauer, S., EMmetT, P.H. \& Teller, E., 1938. Adsorption of gases in multimolecular layers. Journal of the American Chemical Society. 60. 309-319.

Burford, J.R., DEShPANDE, T.L., GREENLAND, D.J. \& QuiRK, J.P., 1964. Influence of organic materials on the determination of the specific surface areas of soils. Journal of Soil Science. 15. 192-201.

BUZÁs I. (szerk.), 1988. Talaj- és agrokémiai vizsgálati módszerkönyv 2. A talajok fizikai-kémiai és kémiai vizsgálati módszerei. Mezőgazdasági Kiadó, Budapest.

BuZÁs I. (szerk.), 1993. Talaj- és agrokémiai vizsgálati módszerkönyv 1. A talaj fizikai, vízgazdálkodási és ásványtani vizsgálata. Inda 4231 Kiadó Budapest.

CARTER, D.L., HEILMAN, M.D. \& GONZALEZ, C.L., 1965. Ethylene glycol monoethyl ether for determining surface area of silicate minerals. Soil Science. 100 (5). 356-360.

Cerato, A.B. \& Lutenegger, A.J., 2002. Determination of surface area of finegrained soils by the ethylene glycol monoethyl ether (EGME) method. Geotechnical Testing Journal. 25. 1-7. 
CHEN, G., PAN, J., HAN, B. \& YAN, H., 1999. Adsorption of methylene blue on montmorillonite. Journal of Dispersion Science and Technology. 20 (4). 1179-1187.

CHENU, C. \& STOTZKY, G. 2002. Interactions between microoranizms and soil particles: An overview. In: Interactions between soil particles and microorganisms and their impact on the terrestrial ecosystem (eds.: HuANG, P.M., BollaG, J-M. \& SENESI, N.). John and Wiley. Chichester, United Kingdom. 1-40.

CieŚlA, J., SokoŁOWsKa, Z., WiTKowska-WALCZAK, B. \& SkIC, K., 2018. Adsorption of water vapour and the specific surface area of arctic zone soils (Spitsbergen). International Agrophysics. 32 (1). 19-27.

Di GlÉRIA, J., Klimes-SzMIK, A. \& DVORACSEK, M., 1957. Talajfizika és kolloidika. Akadémia Kiadó. Budapest.

DEFLAUN, M.F. \& MAYER, L.M., 1983. Relationship between bacteria and grain surfaces in intertidal sediments. Limnology and Oceanography. 28 (5). 873-881.

DE JONG, E., 1999. Comparison of three methods of measuring surface area of soils. Canadian Journal of Soil Science. 79 (2). 345-351

Dragun, J., 1998. The soil chemistry of hazardous materials. Amherst scientific publishers. Amherst. Massachusetts.

FARRER, D.M. \& COLEMAN, J.D., 1967. The correlation of surface area with other properties of nineteen British clay soils. Journal of Soil Science. 18. 118-124.

FILEP, Gy., 1988. Talajkémia. Akadémiai Kiadó. Budapest.

FINK, D.H. \& JACKSON, R.D., 1973. An equation for describing water vapor adsorption isotherms of soils. Soil Science. 116 (4). 256-261.

GREENLAND, D.J. \& HAYES, M.H.B., 1981. The chemistry of soil processes. John Wiley $\&$ Sons. New York.

HAJNOS, M., 2011. Porosimetry. In: Encyclopedia of Agrophysics (Eds.: GLIŃSKI J., HorABIK J. \& LIPIEC J.). Encyclopedia of Earth Sciences Series. Springer. Dordrecht. 647-650.

Hall, M. \& CATON, S., 2017. Am I who I say I am? Unobtrusive self-representation and personality recognition on Facebook. PLoS ONE. 12 (9). e0184417.

HARGITAI, L., 1974. R-érték meghatározások a humuszminőség gyakorlati értékelésére. A Kertészeti Egyetem Közleményei. 37 (5). 239-245.

HARGITAI, L., 1983. Talajok környezetvédelmi kapacitásának meghatározása humuszállapotuk alapján. Agrokémia és Talajtan. 32 (3-4). 360-364.

HEIL, D. \& SPOSITO, G., 1995. Organic matter role in illitic soil colloids flocculation: III. Scanning force microscopy. Soil Science Society of America Journal. 59 (1). 266-269.

HERNÁDI, H. \& MAKÓ, A., 2012. Szerves folyadékgőzök adszorpciója talajokon. In: Köolajszármazékok a talajban: talajfizikai kutatások (Szerk.: MAKÓ, A. \& HERNÁDI, H.) 2. kiadás. Pannon Egyetem Georgikon Kar. Keszthely. 78-92.

HolforD, I.C.R. \& MATTINGLY, G.E.G., 1975. Surface areas of calcium carbonate in soils. Geoderma. 13. 247-255.

HorowitZ, A.J. \& ELRICK, K.A., 1987. The relation of stream sediment surface area, grain size and composition to trace element chemistry. Applied Geochemistry. 2. 437-451.

Jahanban, L., Ebrahimi, E., Moradi, S., FAllah, M., ARAni, L.G. \& MoHAJER, R., 2018. Estimation of soil specific surface area using some mechanical properties of soil by artificial neural networks. Environmental Monitoring and Assessment. 190 (10). 614. 
Józefaciuk, G., Murányi, A., Szatanik-Kloc, A., FARKas, Cs. \& GyuriczA, Cs., 2001. Changes of surface, fine pore and variable charge properties of a brown forest soil under various tillage practices. Soil and Tillage Research. 59. 127-135.

JóZEFACIUK, G., TóTH, T. \& SZENDREI, G., 2006. Surface and micropore properties of saline soil profiles. Geoderma. 135. 1-15.

KAiser, K. \& GugGENBERGER, G., 2003. Mineral surfaces and soil organic matter. European Journal of Soil Science 54. 219-236.

Kögel-Knabner, I., Guggenberger, G., Kleber, M., Kandeler, E., Kalbitz, K., SCHEU, S., EUSTERHUES, K. \& LEINWEBER, P., 2008. Organo-mineral associations in temperate soils: Integrating biology, mineralogy, and organic matter chemistry. Journal of Plant Nutrition and Soil Science. 171. 61-82.

LUCKE, B. \& SCHMIDT, U., 2015. Grain size analysis of calcareous soils and sediments: inter-method comparison with and without calcium carbonate removal. In: Soils and Sediments as Archives of Environmental Change. Geoarchaeology and Landscape Change in the Subtropics and Tropics (Eds.: LUCKE, B., BÄUMLER, R., \& SCHMIDT, M.) Erlangen, Franconian Geographical Society. 83-96.

MAKÓ, A. \& HERNÁDI, H., 2012. Kőolajszármazékok viselkedése a talajban. In: Kőolajszármazékok a talajban: talajfizikai kutatások (Szerk.: MAKó, A. \& HERNÁDI, H.) 2. kiadás. Pannon Egyetem Georgikon Kar. Keszthely. 13-77.

MAKó, A., Kocsis, M., BARNA, Gy. \& TóTH, G. 2017. Mapping the storing and filtering capacity of European soils. EUR 28392. Publications Office of the European Union. Luxembourg.

MAYER, L.M. \& XING, B., 2001. Organic matter-surface area relationships in acid soils. Soil Science Society of America Journal. 65. 250-258.

MikutTA, R., Kleber, M., KAISER, K. \& JAHN, R., 2005. Review: organic matter removal from soils using hydrogen peroxide, sodium hypochlorite, and disodium peroxodisulfate. Soil Science Society of America Journal. 69 (1). 120-135.

MSZ-08-0205-78. MÉM Ágazati Szabvány 1979. A talaj fizikai és vízgazdálkodási tulajdonságainak vizsgálata. Budapest.

MSZ-08-0206-2-78. MÉM Ágazati Szabvány 1979. A talaj egyes kémiai tulajdonságainak vizsgálata. Laboratóriumi vizsgálatok (pH-érték, szódában kifejezett fenolftalein lúgosság, vízben oldható összes só, hidrolitos /y1-érték/ és kicserélődési aciditás /y2-érték/). Budapest.

PENNELl, K.D., BOYD, S.A. \& ABRIOLA, L.M., 1995. Surface area of soil organic matter reexamined. Soil Science Society of America Journal. 59. 1012-1018.

Petersen, L.W., Moldrup, P., Jacobsen, O.H. \& Rolston, D.E., 1996. Relations between specific surface area and soil physical and chemical properties. Soil Science. 161. 9-21.

QUIRK, J.P., 1955. Significance of surface areas calculated from water vapor sopption isotherms by use of the BET equation. Soil Science. 80 (6). 423-430.

Rawlins, B.G., Turner, G., Mounteney, I. \& Wildman, G., 2010. Estimating specific surface area of fine streambed sediments from geochemistry. Applied Geochemistry. 25 (9). 1291-1300.

Ristori, G.G., Sparvoli, E., LANDi, L. \& MARTelloni, C., 1989. Measurement of specific surface areas of soils by p-Nitrophenol adsorption. Applied Clay Science. 4. 521-532. 
Santamarina, J.C., KLein, K.A., WANG, Y.H. \& PrencKe, E., 2002. Specific surface: determination and relevance. Canadian Geotechnical Journal. 39. 233-241.

STEFANOVITS, P., 1963. Magyarország talajai. Akadémiai Kiadó. Budapest.

SkIC, K., BoguTA, P. \& SoKOŁOWSKA, Z., 2016. Analysis of the sorption properties of different soils using water vapour adsorption and potentiometric titration methods. International Agrophysics. 30 (3). 369-374.

SoKOŁOWSKA, Z., 2011. Specific surface area of soils and plants. In: Encyclopedia of Agrophysics (Eds.: GLIŃSKI, J., HoRABIK, J. \& LIPIEC, J.) Encyclopedia of Earth Sciences Series. Springer. Dordrecht. 839-844.

SokoŁowska, Z., Borówko, M., Reszko-Zygmunt, J. \& SokoŁowski, S., 2002. Adsorption of nitrogen and water vapor by alluvial soils. Geoderma. 107. 33-54.

SOKOŁOWSKA, Z., HaJnOS, M., Elias, E.A. \& AlaILY, F., 2004. Characteristics of surface area of Vertisols from the Gezira region in Sudan. International Agrophysics. 18. 83-90.

THENG, B.K.G., 1974. The chemistry of clay organic reactions. Adam Hilger Ltd. London.

Theng, B.K.G., Ristori, G.G., SAnti, C.A. \& Percival, H.J., 1999. An improved method for determining the specific surface areas of topsoils with varied organic matter content, texture and clay mineral composition. European Journal of Soil Science. 50. 309-316.

TOMBÁCZ, E., LÁMfalusi, E., SzeKERES, M. \& MichÉli, E., 1996. Humuszanyagok hatása a talajok felületi tulajdonságaira. Agrokémia és Talajtan. 45 (3-4). 238-248.

TOMBÁcz, E., SzEKERES, M., BARANYI, L. \& MichÉLI, E., 1998. Surface modification of clay minerals by organic polyions. Colloids and Surfaces A: Physicochemical and Engineering Aspects. 141. 379-384.

UTKAEVA, V.F., 2007. Specific surface area and wetting heat of different soil types in European Russia. Eurasian Soil Science. 40 (11). 1193-1202.

Vdović, N., Pikelu, K., JuRina, I., IVAnić, M., DunAto, N. \& ŠTefan, A., 2019. The implications of sample preparation on the particle size distribution of soil. Journal of Plant Nutrition and Soil Science. 182 (2). 277-285.

WAGAI, R., MAYER, LM. \& KITAYAMA, K., 2009. Extent and nature of organic coverage of soil mineral surfaces assessed by a gas sorption approach. Geoderma. 149. 152-160.

WhitFIELD, C.J. \& REID, C., 2013. Predicting surface area of coarse-textured soils: Implications for weathering rates. Canadian Journal of Soil Science. 93 (5). 621-630.

YAMAMOTO, N. \& LOPEZ, G., 1985. Bacterial abundance in relation to surface area and organic content of marine sediments. Journal of Experimental Marine Biology and Ecology. 90. 209-220

YANG, H., 2013. The case for being automatic: introducing the Automatic Linear Modeling (LINEAR) procedure in SPSS Statistics. Multiple Linear Regression Viewpoints. 39. 27-37.

YuKSELEN, Y. \& KAYA, A., 2006. Comparison of methods for determining specific surface area of soils. Journal of Geotechnical and Geoenvironmental Engineering. 132 (7). 931-936.

ZHU, X., CAI, J., XU, X. \& XIE, Z., 2013. Discussion on the method for determining BET specific surface area in argillaceous source rocks. Marine and Petroleum Geology. 48. 124-129. 


\title{
Analysis of correlations between BET-specific surface area, humus materials and other soil properties on typical Hungarian soil types
}

\author{
${ }^{1}$ S. MolnÁR, ${ }^{1} *$ G. BARNA, ${ }^{1}$ E. Draskovits, ${ }^{2}$ R. FÖLdÉnyi, ${ }^{3}$ H. HERnÁdI, \\ ${ }^{1}$ Z. BAKACSI, ${ }^{1,4}$ A. MAKÓ \\ ${ }^{1}$ Institute for Soil Science and Agricultural Chemistry of the Hungarian Academy of \\ Sciences, Budapest; \\ ${ }^{2}$ University of Pannonia, Soós Ernő Water Technology Research and Development \\ Center, Nagykanizsa; \\ ${ }^{3}$ Pannon University, Georgikon Faculty, Institute of Plant Protection, Keszthely; \\ ${ }^{4}$ University of Pannonia, Georgikon Faculty, Department of Soil Science and \\ Environmental Informatics, Keszthely
}

\section{Summary}

In our study, we examined 27 different Hungarian soil profiles to reveal the relationship between $\mathrm{N}_{2}$-BET specific surface area $\left(\mathrm{N}_{2}\right.$-BET SSA) and other soil physical properties.

According to the univariate statistical analysis, it can be stated that the soil particle size distribution shows the closest correlation to the SSA. The clay content has a strong positive correlation with it, on the contrary the increasing sand content causes decreasing specific surface area. It can be proved that the calcium carbonate and humus content have a not too strong negative correlation, but Hargitai's humic stability index has a weak positive correlation with the $\mathrm{N}_{2}$-BET values. We could not verify the relationship between soil $\mathrm{pH}$ and specific surface area.

We also examined the combined effect of different soil properties on the $\mathrm{N}_{2}$ BET SSA and the role of the soil class and soil types. Based on the entire database, the most important factors of the $\mathrm{N}_{2}$-BET SSA are the clay content, the humus content, and eventually the carbonate content. If we also have information about the quality of humic matter,then the clay content, the humus content, the humus quality and the $\mathrm{pH}$ are those soil properties that primarily affect the size of the $\mathrm{N}_{2}$-BET SSA. It has been found that the accuracy of the specific surface area estimation models can be improved by taking into consideration the taxonomic classification of the soils (soil main type, soil type) as a category variable. In some cases, we do not have direct measurement results, however, the knowledge of the soil taxonomy provides a lot of indirect information of the soils' parameters and their combined effects.

Key words: specific surface area, clay content, organic matter content, humus quality, $\mathrm{N}_{2}$-BET 
A BET-fajlagos felület, a humuszanyagok ... összefüggéseinek vizsgálata ...

\section{Tables and Figures}

Table 1. The locations of the soil profiles and the classification of soils according to Hungarian genetic soil taxonomy. (1) Settlement; (2) Soil class, (3) Soil type and its code.

Table 2. The main parameters of the $\mathrm{N}_{2}$-BET SSA database. (1) Average; (2) Minimum; (3) Maximum; (4) Deviation; (5) Number of samples; (6) Clay content measured by the Hungarian Standard; (7) Silt content measured by the Hungarian Standard; (7) Sand content measured by the Hungarian Standard; (9) Humus content; (10) Q - stability index; (11) K - Humus stability index

Table 3. The relationship between the examined parameters. (Pearson correlation matrix) (1) Clay content measured by the Hungarian Standard; (2) Silt content measured by the Hungarian Standard; (3) Sand content measured by the Hungarian Standard; (4) Humus content; (5) K - Humus stability index

Figure 1. The locations of the soil profiles. (For the detailed explanation see Table 1.)

Figure 2. The particle size distribution values measured by MSZ (Hungarian Standard) on USDA textural triangles. (1) Clay. (2) Silt. (3) Sand. The abbreviations for the textural classes are a: clay; av: clay loam; v: loam; vh: loamy sand; h: sand; ha: sandy clay; hav: sandy clay loam; hv: sandy loam; i: silt; iv: silt loam; ia: silty clay; iav: silty clay loam

Figure 3. The $\mathrm{N}_{2}$-BET SSA of the soil samples after soil classification unit. Meaning of codes: 50 - Skeletal soils; 60-80: Lithomorphous forest soils; 90-160: Brown forest soils; 170-190: Chernozem soils; 300: Meadow soil.

Figure 4. The relationship between the $\mathrm{N}_{2}$-BET SSA and other soil properties for the soil samples. Y-axis: BET-specific surface area. (1) Clay. (2) Sand. (3) Humus content. (4) Humus stability coefficient, K. (5) Calcium carbonate content. (6) Soil reaction.

Figure 5. The models of $\mathrm{N}_{2}$-BET SSA affecting by soil properties. A.: entire database $(\mathrm{N}=204)$; B.: samples containing more than $0.5 \%$ humus $(\mathrm{N}=132)$. (The thickness of the lines shows the strength of the effects. See detailed description in the text.) (1) Clay. (2) Humus content. (3) Calcium carbonate. (4) Constant. (5) Humus stability coefficient, K. (6) Soil reaction.

Figure 6. The models of $\mathrm{N}_{2}$-BET SSA affecting by soil properties (added to the taxonomic classification of the soils as a category variable). A.: entire database $(\mathrm{N}=204)$; B.: samples containing more than $0.5 \%$ humus $(\mathrm{N}=132)$. (The thickness of the lines shows the strength of the effects.) (1) Constant. (2) Clay. (3) Humus. (4) Soil main type. (5) Calcium carbonate. (6) Sand. (7) Humus stability coefficient, K. (8) Soil reaction.

Open Access nyilatkozat: A cikk a Creative Commons Attribution 4.0 International License (https://creativecommons.org/licenses/by/4.0) feltételei szerint publikált Open Access közlemény, melynek szellemében a cikk bármilyen médiumban szabadon felhasználható, megosztható és újraközölhetö, feltéve, hogy az eredeti szerző és a közlés helye, illetve a CC License linkje és az esetlegesen végrehajtott módosítások feltüntetésre kerülnek. (SID_1) 